\title{
Clinical update on cancer: molecular oncology of head and neck cancer
}

\author{
Y Suh ${ }^{1}$, I Amelio ${ }^{2}$, T Guerrero Urbano ${ }^{3}$ and M Tavassoli ${ }^{*, 1}$
}

Head and neck cancers encompass a heterogeneous group of tumours that, in general, are biologically aggressive in nature. These cancers remain difficult to treat and treatment can cause severe, long-term side effects. For patients who are not cured by surgery and/or (chemo)radiotherapy, there are few effective treatment options. Targeted therapies and predictive biomarkers are urgently needed in order to improve the management and minimise the treatment toxicity, and to allow selection of patients who are likely to benefit from both nonselective and targeted therapies. This clinical update aims to provide an insight into the current understanding of the molecular pathogenesis of the disease, and explores the novel therapies under development and in clinical trials.

Cell Death and Disease (2014) 5, e1018; doi:10.1038/cddis.2013.548; published online 23 January 2013

Subject Category: Cancer

\section{Facts}

- Head and neck squamous cell carcinoma (HNSCC) is the sixth leading cause of cancer worldwide. Exposure to carcinogens (tobacco and alcohol) and infection with human papillomavirus (HPV) are the most common risk factors.

- The main molecular determinants in HNSCC are the abrogation of $\mathrm{p} 53$ and retinoblastoma (pRb) pathways that lead to uncontrolled cell replication.

- Mutations in EGFR-MEK, NOTCH, PI3K, PTEN and AKT pathways are frequently observed in HNSCC. These mutations cooperate to create aberrant mitogenic/survival signalling.

- Changes in metabolism and tumour hypoxia contribute to resistance to current therapies and tumour recurrence.

\section{Open Questions}

- Although HNSCC is a heterogeneous disease, the current molecular classification distinguishes only HPV-positive and HPV-negative tumours: further investigation to genetically classify HNSCC subgroups is needed.

- HNSCC metastasises primarily and frequently to regional lymph nodes (more rarely to other organs via haematogenous spread): genetic profiles should aid the identification of causative genes of metastasis.
- Radioresistance has been identified as an important cause of locoregional treatment failure, and identification of molecular mechanisms underpinning this could contribute to better treatment selection and outcome.

- The genetics of HNSCC is complex, especially of HPVnegative cancers: a detailed understanding of the molecular basis and identification of driving mutations and drugable targets should lead to personalised therapies.

Head and neck cancer accounts for $\sim 4 \%$ of all malignancies worldwide and $5 \%$ mortality of all cancers, ${ }^{1}$ and includes the following subsites: oral cavity, nasopharynx, oropharynx, hypopharynx, larynx, paranasal sinuses, nasal cavity and salivary glands. Over $90 \%$ are squamous cell carcinomas (head and neck squamous cell carcinoma (HNSCC)), arising from the epithelial cells that line the mucosal surfaces of the head and neck.

More than $75 \%$ of cases of HNSCC are attributable to smoking and alcohol consumption. Smoking increases the risk by $\sim 10$-fold compared with never smokers, and heavy alcohol intake is an independent risk factor. ${ }^{2}$ The combined effect of tobacco and alcohol causes a greater than multiplicative risk. ${ }^{3}$ Public health measures have been successful in reducing the use of tobacco, and therefore the incidence of HNSCC overall has been decreasing over the past 30 years in developed countries. However, there has been a dramatic increase in the incidence rates of oropharyngeal (tonsil and base of tongue) cancers because of infection with high-risk human papillomavirus (HPV). ${ }^{4,5}$

\footnotetext{
${ }^{1}$ Department of Molecular Oncology, King's College London, Guy's Hospital, Hodgkin Building, London SE1 1NU, UK; ${ }^{2}$ Medical Research Council, Toxicology Unit, Leicester University, Leicester LE1 9HN, UK and ${ }^{3}$ Clinical Oncology Department, Lambeth Wing, St Thomas' Hospital, Westminster Bridge Road, London SE1 7EH, UK ${ }^{*}$ Corresponding author: M Tavassoli, Department of Molecular Oncology, Head and Neck Oncology Group, Dental Institute, King's College London, Hodgkin Building, London SE1 1UL, UK. Tel: +44 (0)20 7848 6109; Fax: +44 (0)20 7848 6210; E-mail: Mahvash.tavassoli@ kcl.ac.uk

Keywords: head and neck squamous cell carcinoma; targeted therapy; HPV; metabolism; hypoxia; biomarkers

Abbreviations: HNSCC, head and neck squamous cell carcinoma; HPV, human papillomavirus; ATM, ataxia telangiectasia mutated; ATR, ataxia telangiectasia and Rad3-related; EGFR, epidermal growth factor receptor; MAPK, mitogen-activated protein kinase; STAT3, signal transducer and activator of transcription 3; JAK, Janus kinase; PI3K, phosphoinositide 3-kinase; mAb, monoclonal antibody; PTEN, phosphatase and tensin homology; mTOR, mammalian target of rapamycin; GDP, guanosine diphosphate; GTP, guanosine triphosphate; VEGF, vascular endothelial growth factor receptor; PDGFR, platelet-derived growth factor receptor; HGF, hepatocyte growth factor; ATP, adenosine triphosphate

Received 04.11.13; revised 04.12.13; accepted 05.12.13; Edited by A Stephanou
} 
At present, treatment of an individual cancer is typically determined in a multidisciplinary setting, with the histological subtype, subsite, staging information, patient fitness, baseline swallow and airway function guiding management decisions. Approximately one-third of patients present with early-stage disease and these patients are treated with either surgery or radiotherapy depending on the primary tumour site, with cure rates of $70-90 \% .^{6}$ The majority of patients, however, present with locally advanced stage disease. Radical treatment in this situation requires multimodality therapy with surgery, commonly followed by postoperative radiotherapy or chemoradiotherapy, or organ preserving primary radiotherapy, with or without chemotherapy, with reduced cosmetic compromise. ${ }^{7}$ These treatments are intensive and associated with severe acute toxicity, such as mucositis, dermatitis and dysphagia, and long-term sequelae, for example, sensorineural hearing loss, permanent xerostomia and altered swallowing function. Despite recent advances in both surgical and radiotherapy delivery techniques, up to $50 \%$ of locally advanced tumours relapse usually within the first 2 years after treatment, with limited options for salvage surgery or reirradiation. ${ }^{6,7}$ Several chemotherapy agents can be used for inoperable recurrences or metastatic disease, with response rates of only $10-35 \%$ and median survival of $6-12$ months. $^{8}$

Beyond HPV status, no validated molecular characterisation of the disease has been established. However, preliminary work suggests the existence of several different molecular classes of HNSCC (basal, mesenchymal, atypical and classical), based on the biological characteristics of differentially expressed genes in each subtype. ${ }^{9}$ Genetic and molecular advances have revealed new genes and pathways involved in the development and progression of HNSCC, creating opportunities to explore novel therapeutic targets. HNSCC research has shifted to focus on biomarker discovery for diagnosis, prognosis and prediction of treatment response, alongside the development of targeted therapies, with the ultimate goal of personalising therapy for each individual patient.

\section{TP53/RB Pathway}

Tumour suppressor protein p53 plays a key role in the regulation of genes involved in cell cycle and growth arrest, DNA repair or apoptosis, thereby maintaining genomic stability. ${ }^{10}$ In response to DNA damage, p53 can arrest the cell cycle and activate repair or initiate apoptosis. p53 controls a significant spectrum of genes involved in various pathways ${ }^{11}$ these include recently discovered biochemical pathways, such as the connection of IL-7Ra to telomere erosion, ${ }^{12}$ the metabolism of the cell ${ }^{13}$ and the silencing of repeats and noncoding RNA. ${ }^{14}$ This intense gene expression results in a very fine regulation of life, death or senescence. ${ }^{15,16}$ p53 level is regulated by mouse double minute 2 homolog (MDM2), an E3 ubiquitin protein ligase that binds to p53 and causes its degradation. MDM2 is inhibited by $\mathrm{p} 14^{\mathrm{ARF}}$ that is encoded by the gene $C D K N 2 A$, protecting p53 from degradation. ${ }^{10,17}$ Ataxia telangiectasia mutated (ATM) and ataxia telangiectasia and Rad3-related (ATR) pathways sense DNA damage and phosphorylate the cell cycle checkpoint kinases CHK1 and $\mathrm{CHK} 2$, resulting in p53 activation. p53 transactivates a number of proteins with roles in cell cycle arrest and apoptosis. Together with p53, its more recently discovered family members, p63 and p73, have also been shown to play important roles in cell cycle regulation and apoptosis, and their link to various types of cancer including HNSCC is being investigated. ${ }^{18}$

The tumour suppressor protein retinoblastoma $(\mathrm{pRb})$ controls the expression of genes involved in cell cycle progression through the $\mathrm{G} 1$ restriction point. $\mathrm{pRb}$ binds and inhibits E2F transcription factors that induce expression of S-phase genes and cell proliferation. Mitogenic signals activate cyclin D1/CDK4/CDK6 complexes that phosphorylate $\mathrm{pRb}$, resulting in the release of E2F. The cyclin D1-CDK4/6 complexes are inhibited by $\mathrm{p} 16^{\mathrm{INK} 4 \mathrm{~A}}$ that is encoded by the gene CDKN2A, and also p21 ((cyclin-dependent kinase inhibitor 1 (CDKN1)) that binds to the complexes and prevents them from phosphorylating $\mathrm{pRb}$, thereby halting progression into S phase. ${ }^{17}$

Mutations in p53 and pRb pathways result in limitless replicative potential and immortalisation. TP53 mutations can occur throughout the entire gene but the majority are because of a missense mutation in the DNA-binding domain. These mutations can result in a number of consequences including inhibition of function, tumour suppressor loss or occasionally gain of function. ${ }^{19}$ Mutation of the TP53 tumour suppressor gene is one of the earliest and most frequently detectable genetic alterations in HNSCC reported in 50-80\% of cases, ${ }^{20,21}$ and can also be detected in premalignant dysplastic lesions and in histopathologically negative tumour surgical margins. ${ }^{22,23}$ A recent mutational screening in 12 types of cancer has revealed mutations of p53 in $69.8 \%$ of HNSCC (Figure 1). From this analysis, HNSCC appears the most common p53 mutation-carrying cancer type after ovarian cancer and lung squamous cell carcinoma. ${ }^{24}$ Increased TP53 mutation rate is associated with tobacco and alcohol use in HNSCC and also with increased risk of progression to cancer. ${ }^{25,26}$ In p53 wild-type tumours, p53 function may be inactivated by other mechanisms, such as HPV infection, overexpression or amplification of MDM2 and deletion of the $\mathrm{p} 14^{\mathrm{ARF}}$ gene. ${ }^{10}$

$\mathrm{pRb}$ is targeted early in the carcinogenesis of HNSCC through inactivation of the tumour-suppressive CDKN2A gene, with mutations seen in 7-9\% and copy number losses in a further $20-30 \%$ of cases. ${ }^{20,27}$ The CCND1 gene, which encodes cyclin D1 on chromosome 11q13, is amplified or overexpressed in over $80 \%$ of HNSCC. ${ }^{28}$ TP53 mutation, loss of p16 $6^{\mathrm{INK} 4 \mathrm{~A}}$ and overexpression of cyclin D1 are all associated with reduced survival. ${ }^{21,29}$ In addition, TP53 mutation is predictive of poor response to chemotherapy and locoregional recurrence following radiotherapy. ${ }^{30,31}$

Restoring or modulating p53 as targeted therapy has been an area of intensive research for decades, with limited success. Only one phase III study has been completed using adenoviral p53 gene therapy in HNSCC. This showed that patients with wild-type p53 had better response to Ad-p53 gene therapy, whereas mutant p53 patients responded better to methotrexate chemotherapy, suggesting a potential of p53 profile as predictive biomarker of response to specific type of therapy. ${ }^{32}$ p53-reactivating small molecules are currently under investigation in HNSCC cell lines, ${ }^{33}$ and other 


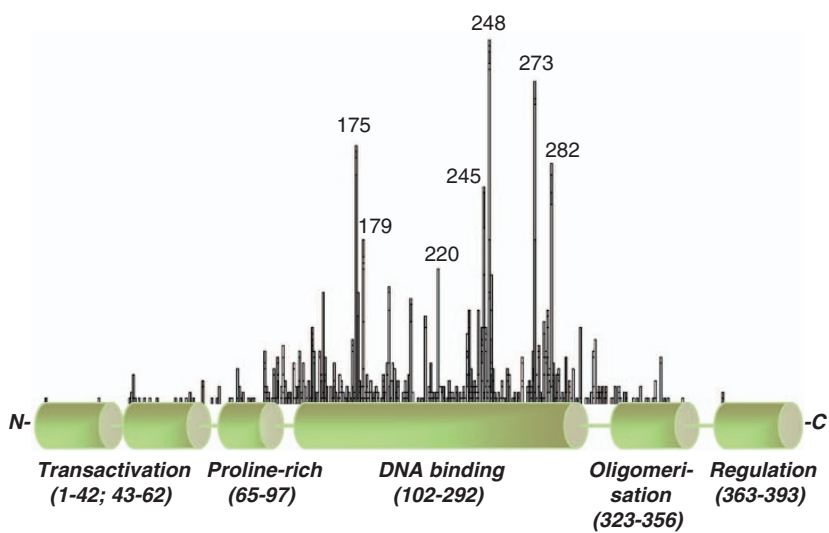

Figure 1 The p53 structure with different protein domains (transactivation domain, proline-rich domain, DNA-binding domain, oligomerisation domain and regulation domain). Vertical lines indicate the occurrence of mutation of the amino acid residues in HNSCC (data from COSMIC website: cancer.sanger.ac.uk cancergenome/projects/cosmic)

strategies include targeting $C D K N 2 A$ to reactivate $\mathrm{p} 16^{\mathrm{INK} 4 \mathrm{~A}}$ and CDK inhibitors. A phase I study of a CDK inhibitor in combination with radiation has recently completed recruitment (NCT00899054, Table 1).

\section{Epidermal Growth Factor Receptor (EGFR) Pathway}

EGFR (ErbB1) is a member of the ErbB/HER2 family of transmembrane receptor tyrosine kinases. Other members include HER2 (ErbB2), ErbB3 and ErbB4 and they play a major role in cell proliferation, differentiation, survival and migration. EGFR is composed of an extracellular ligandbinding domain, a transmembrane segment and a cytoplasmic domain with tyrosine kinase activity. It is activated by a number of ligands including EGF, transforming growth factor- $\alpha$ and amphiregulin. Ligand binding results in a conformational change in EGFR and homo- or hetero-dimerisation with other ErbB family members, leading to autophosphorylation and receptor activation. This results in the activation of downstream signal transduction cascades including the Ras/Raf/ mitogen-activated protein kinase (MAPK), phosphoinositide 3-kinase (PI3K)/AKT and Janus kinase (JAK)/signal transducer and activator of transcription 3 (STAT3) pathways. ${ }^{34}$ The EGF-bound EGFR can also translocate to the nucleus to function as a transcription factor. One of the nuclear targets is CCND1 that encodes cyclin D1 protein involved in cell cycle progression (Figure 2). ${ }^{35}$

EGFR protein is detected by immunohistochemistry in over $90 \%$ of HNSCC cases. EGFR overexpression is mainly at the transcriptional level as there are few EGFR-activating mutations in HNSCC. ${ }^{36}$ Approximately $10-30 \%$ of HNSCC display EGFR gene amplification, and EGFR point mutations are reported in only $1-7 \%$ of patients. ${ }^{37,38} \mathrm{~A}$ mutant form of EGFR, EGFRvIII, resulting from an in-frame deletion of exons $2-7$ in the extracellular domain, has been reported in $42 \%$ of HNSCC. ${ }^{39}$ The intensity of expression, as assessed by immunohistochemistry, has been shown to indicate poor prognosis, as has EGFR gene copy number. ${ }^{40,41}$ However, the gene copy number has not been found to be a predictive biomarker of efficacy with EGFR-directed therapy, ${ }^{41}$ unlike specific mutations in non-small-cell lung cancer.

EGFR can be targeted either by inhibition of the extracellular ligand binding using monoclonal antibodies (mAbs), such as cetuximab, or by inhibition of the tyrosine kinase domain with a small molecule (TKIs), such as gefitinib, erlotinib and lapatinib. Cetuximab is a chimeric humanmurine IgG1 mAb directed specifically against EGFR, resulting in inhibition of cell cycle progression, angiogenesis and metastasis, induction of apoptosis and synergy with radiotherapy and chemotherapy. It remains the only FDA-approved and European Medicines Agency-approved targeted therapy in HNSCC and its use is not dependent on EGFR status. It is used in combination with radiotherapy in locally advanced HNSCC, in combination with platinum-based chemotherapy and 5-fluorouracil for first-line treatment of recurrent/metastatic disease, and as a single agent in recurrent/metastatic disease after failure of platinum-based chemotherapy. ${ }^{42,43}$ Skin toxicity is a common side effect with cetuximab treatment and this clinical feature has been suggested as a biomarker for response to cetuximab, with response rates of $33 \%$ observed in patients with skin rash compared with $7 \%$ in those who do not develop skin toxicities. ${ }^{44}$ Panitumumab is a fully humanised $\mathrm{mAb}$ against EGFR in use in colorectal cancer. In HNSCC, a phase III trial of panitumumab in combination with chemotherapy did not show an improvement in survival, although retrospective analysis showed that median overall survival in p16 (surrogate marker for HPV)-negative patients was longer in the panitumumab group than in the control group. ${ }^{45}$ Other promising mAbs currently in phase III trials include zalutumumab and nimotuzumab (NTC00496652 and NTC00957086). Despite the high expression of EGFR in HNSCC, EGFR inhibition with mAbs has only a modest effect. Preclinical studies investigating resistance to EGFR inhibition have suggested mechanisms such as increased nuclear localisation of EGFR, cross-talk of EGFR with other receptor tyrosine kinases, such as HER2 and ErbB3, as well as upregulation of these receptors and their ligands. ${ }^{46}$

TKIs block the activation and phosphorylation of EGFR, and these drugs are given orally as they are well absorbed across the gastrointestinal tract. Gefitinib and erlotinib, currently used in lung cancer, inhibit only EGFR and have not been shown to be efficacious in HNSCC to date. Because of the potential resistance mechanisms, TKIs that have action against multiple ErbB family receptors are under investigation. Lapatinib has dual specificity for EGFR and HER2 and is in use in breast cancer. In HNSCC trials, it has shown activity in p16-negative tumours in combination with chemoradiation, ${ }^{47}$ and is currently being evaluated in the recurrent/metastatic setting in combination with capecitabine chemotherapy (NCT01044433), and in a phase III adjuvant trial (NCT 00424255). Afatinib irreversibly blocks EGFR, HER2 and ErbB4 and is being investigated in the recurrent/metastatic, neoadjuvant and adjuvant settings (NCT 01856478, NCT01538381 and NCT01345669).

\section{NOTCH Pathway}

$\mathrm{NOTCH} 1$ signalling is involved in a number of biological functions, including regulation of self-renewal capacity, 
Table 1 Targeted therapies in HNSCC

\begin{tabular}{|c|c|c|c|c|}
\hline Type of drug & Drug & Target & Stage of development & NCT number \\
\hline Adenovirus gene therapy & $\begin{array}{l}\text { Advexin } \\
\text { ONYX-015 }\end{array}$ & $\begin{array}{l}\text { p53 } \\
\text { p53 }\end{array}$ & $\begin{array}{l}\text { Phase III } \\
\text { Approved in China }\end{array}$ & $\begin{array}{l}\text { NCT00064103 } \\
\text { N/A }\end{array}$ \\
\hline CDK inhibitor & P276-00 & $\mathrm{pRb}$ & Phase II & NCT0089954 \\
\hline Monoclonal antibody & $\begin{array}{l}\text { Cetuximab } \\
\text { Panitumumab } \\
\text { Zalutumumab } \\
\text { Nimotuzumab } \\
\text { Bevacizumab }\end{array}$ & VEGFR & $\begin{array}{l}\text { Phase III } \\
\text { Phase III } \\
\text { Phase II }\end{array}$ & $\begin{array}{l}\text { N/A } \\
\text { NCT00756444 } \\
\text { NCT00454779 } \\
\text { NCT00820248 } \\
\text { NCT00496652 } \\
\text { NCT00957086 } \\
\text { NCT01588431 }\end{array}$ \\
\hline Tyrosine kinase inhibitor & $\begin{array}{l}\text { Gefitinib } \\
\text { Erlotinib } \\
\text { Lapatinib } \\
\text { Afatinib } \\
\\
\text { Sorafenib } \\
\text { Sunitinib } \\
\text { Vandetanib } \\
\text { Pazopanib } \\
\text { Axitinib } \\
\text { Nilotinib }\end{array}$ & $\begin{array}{l}\text { VEGFR-2, VEGFR-3, Raf, PDGFR } \\
\text { VEGFR-1, VEGFR-2, VEGFR-3, PDGFR, RET, c-KIT } \\
\text { EGFR, VEGFR, RET } \\
\text { VEGFR-1, VEGFR-2, VEGFR-3, PDGFR, c-KIT } \\
\text { VEGFR-1, VEGFR-2, VEGFR-3, PDGFR, c-KIT } \\
\text { BCR-ABL, c-KIT, PDGFR }\end{array}$ & $\begin{array}{l}\text { Phase II } \\
\text { Phase II } \\
\text { Phase II } \\
\text { Phase II } \\
\text { Phase II } \\
\text { Phase I }\end{array}$ & $\begin{array}{r}\text { NCT00206219 } \\
\text { NCT00684385 } \\
\text { NCT01064479 } \\
\text { NCT00424255 } \\
\text { NCT01856478 } \\
\text { NCT01345669 } \\
\text { NCT01345682 } \\
\text { NCT00939627 } \\
\text { NCT00387335 } \\
\text { NCT00459043 } \\
\text { NCT01377298 } \\
\text { NCT01469546 } \\
\text { NCT01871311 }\end{array}$ \\
\hline MEK inhibitor & Trametinib & MEK & Phase I & NCT01725100 \\
\hline PI3K inhibitor & $\begin{array}{l}\text { PX866 } \\
\text { BKM120 } \\
\text { BYL719 } \\
\text { Rigosertib }\end{array}$ & $\begin{array}{l}\text { PI3K } \\
\text { PI3K } \\
\text { PI3K } \\
\text { PI3K, PLK }\end{array}$ & $\begin{array}{l}\text { Phase II } \\
\text { Phase II } \\
\text { Phase II } \\
\text { Phase II }\end{array}$ & $\begin{array}{l}\text { NCT01204099 } \\
\text { NCT01527877 } \\
\text { NCT01602315 } \\
\text { NCT01807546 }\end{array}$ \\
\hline AKT inhibitor & MK2206 & AKT & Phase II & NCT01349933 \\
\hline mTOR inhibitor & $\begin{array}{l}\text { Rapamycin } \\
\text { Everolimus } \\
\text { Temsirolimus } \\
\text { CC-115 }\end{array}$ & $\begin{array}{l}\text { mTOR } \\
\text { mTOR } \\
\text { mTOR } \\
\text { mTOR, DNA-PK }\end{array}$ & $\begin{array}{l}\text { Phase II } \\
\text { Phase II } \\
\text { Phase II } \\
\text { Phase I }\end{array}$ & $\begin{array}{l}\text { NCT01195922 } \\
\text { NCT01133678 } \\
\text { NCT01172769 } \\
\text { NCT01353625 }\end{array}$ \\
\hline JAK inhibitor & Ruxolitinib & JAK & Phase I & NCT04822756 \\
\hline MET/VEGFR inhibitor & $\begin{array}{l}\text { Foretinib } \\
\text { E7050/Golvatinib }\end{array}$ & $\begin{array}{l}\text { MET, VEGFR-2 } \\
\text { MET, VEGFR-2 }\end{array}$ & $\begin{array}{l}\text { Phase II } \\
\text { Phase II }\end{array}$ & $\begin{array}{l}\text { NCT00725764 } \\
\text { NCT01332266 }\end{array}$ \\
\hline MET inhibitor & LY2801653 & MET & Phase I & NCT01285037 \\
\hline PDK inhibitor & Dichloroacetate & PDK & Phase I & NCT01386632 \\
\hline AMPK activator & Metformin & AMPK & Phase II & NCT01333852 \\
\hline
\end{tabular}

Data source: www.clinicaltrials.gov

survival and promoting terminal differentiation. The NOTCH pathways consist of four receptors bound to the cell membrane, NOTCH 1-4, and two families of ligands, Deltalike (1, 3 and 4) and Jagged (1 and 2). Ligand binding leads to two cleavages of NOTCH1 by TNF $\alpha$-converting enzyme (TACE) and $\gamma$-secretase, resulting in the release of $\mathrm{NOTCH} 1$ intracellular domain (NCID). NCID translocates to the nucleus to promote transcription of its target genes, including the HRT and HES families. NOTCH1 is regulated partly by ubiquitination and degradation that involves FBXW7. ${ }^{48}$

One of the novel findings generated from whole-exome sequencing was the discovery that the second most common mutation in HNSCC is in the NOTCH1 gene, accounting for $14-15 \%$, with mutations in the other NOTCH family members occurring in $3-5 \%$ of HNSCC. ${ }^{20,27}$ Mutations in the FBXW7 gene were also identified in $5 \%$ of cases that have not been previously observed in HNSCC. ${ }^{20}$ Recent integrated analysis has identified the NOTCH pathway to be defective in $66 \%$ of HNSCC patients. Along with the mutations in NOTCH itself, chromosomal aberrations were frequent in JAG1, JAG2, MUMB and MAML1, all of which are involved in modulating $\mathrm{NOTCH}$ signalling. ${ }^{49} \mathrm{NOTCH} 1$ signalling has been reported to be oncogenic, as activating mutations and translocations were found in $\mathrm{NOTCH}$ receptor genes in haematological malignancies. ${ }^{50}$ However, in HNSCC, the majority were nonsense mutations, predicted to result in truncated NOTCH1 proteins lacking the transcriptional activation domains, therefore suggesting a tumour-suppressor role for this pathway in HNSCC.

NOTCH1 signalling promotes terminal differentiation in keratinocytes and skin SCC, and this is negatively regulated by EGFR. Inhibition of EGFR blockade induces keratinocyte 


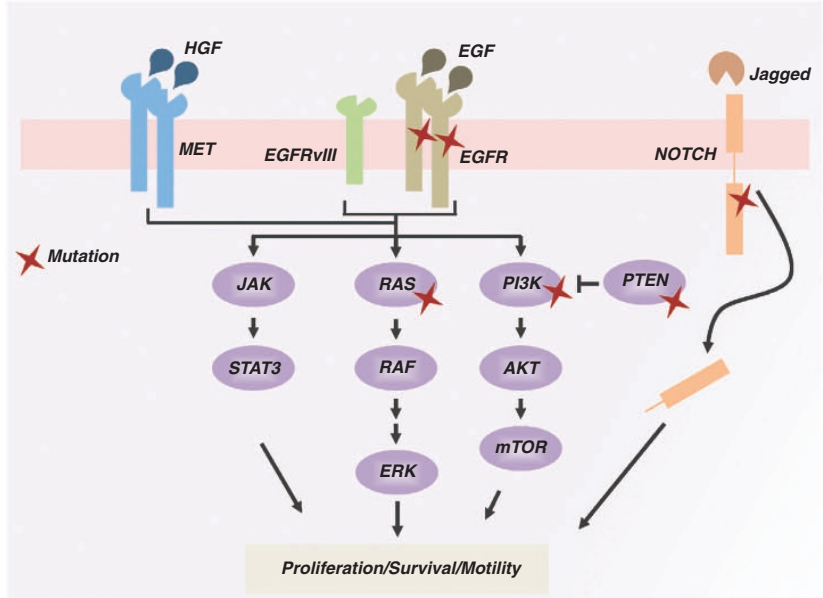

Figure 2 Schematic representation of the major molecular pathways affected in HNSCC. Stars indicate possible mutations in the molecule. EGFR, MET and NOTCH activation can promote molecular signalling through RAS/ERK, PI3K/AKT or JAK/STAT pathways. Aberrant activation of these pathways promotes survival, proliferation and motility of cancer cells, favouring HNSCC tumourigenesis

differentiation. ${ }^{51} \mathrm{NOTCH} 1$ has also been found to be inhibited in basal epithelial cells by the p53-related transcription factor p63 that becomes downregulated during terminal differentiation coinciding with $\mathrm{NOTCH} 1$ upregulation. Overexpression and amplification of TP63 have been observed in the majority of HNSCC. ${ }^{52}$ However, as p63 encodes several isoforms with opposing functions, the precise role of p63 in NOTCH1 signalling and malignant transformation of oral epithelial cells remains to be elucidated.

NOTCH1 signalling has also been linked to suppression of HPV E6 and E7 protein expression in cervical carcinoma cell lines; expression of activated NOTCH1 causes growth inhibition of HPV-positive but not HPV-negative cervical carcinoma cell lines, and results in the downmodulation of HPV-driven transcription of the E6 and E7 viral genes. ${ }^{53}$ The role of NOTCH1 in the complex signalling pathway of HNSCC tumourigenesis needs to be further investigated, but could potentially represent another therapeutic target. Both $\mathrm{NOTCH} 1$ pathway inhibitors that inhibit $\gamma$-secretase and NOTCH1 pathway activators, via inhibition of histone deacetylase, are currently in clinical development.

\section{PI3K/AKT/mTOR Pathway}

PI3Ks are a family of enzymes that phosphorylate the $3^{\prime} \mathrm{OH}$ position of phosphatidylinositols and have important roles in promoting cell growth, differentiation and survival. There are three classes of PI3Ks, each with its own substrate specificity, and class $1 \mathrm{~A}$ is most frequently associated with cancer. Class $1 \mathrm{~A}$ PI3Ks are heterodimers and composed of a $110-\mathrm{kDa}$ catalytic subunit and an $85-\mathrm{kDa}$ regulatory subunit, both of which exist in several isoforms. PI3Ks are activated by RTKs, such as EGFR, and the catalytic subunit phosphorylates phosphatidylinositol1,4-bisphosphate $\left(\mathrm{PIP}_{2}\right)$ to form phosphatidylinositol1,4,5-triphosphate $\left(\mathrm{PIP}_{3}\right)$. $\mathrm{PIP}_{3}$ recruits pleckstrin-homology domain-containing proteins including phosphoinositide-dependent protein-kinase 1 (PDK1) and
AKT to the plasma membrane. Interaction of $\mathrm{PIP}_{3}$ with the $\mathrm{PH}$ (Pleckstrin Homology) domain of AKT results in a conformational change causing phosphorylation of AKT by PKD1 and mammalian target of rapamycin complex 2 (mTORC2). This activates AKT that then phosphorylates proteins involved in cell growth and survival. The tumour-suppressor phosphatase and tensin homology (PTEN) mediates the conversion of $\mathrm{PIP}_{3}$ to $\mathrm{PIP}_{2}$, counteracting the activation of $A K T .{ }^{54} \mathrm{mTOR}$ is a protein kinase that acts downstream of PI3K and AKT and plays an important role in cell growth, survival and protein synthesis regulation. There are two mTOR complexes: mTORC 1 activates ribosomal protein S6 kinase 1 (SK6) and inactivates eukaryotic translation initiation factor $4 \mathrm{E}$-binding protein 1 (4E-BP1), resulting in protein translation and cell growth, whereas mTORC2 activates AKT.

Genetic aberrations of the PI3K pathway are common in HNSCC. One of the isoforms of the $110 \mathrm{kDa}$ catalytic subunit, p110 $\alpha$, is encoded by the PIK3CA gene. This gene is mutated in $6-20 \%$ of HNSCC, especially through the mechanisms of gene amplification and low-level copy number increase. ${ }^{20,27}$ It has been found to be particularly common in HPV-positive HNSCC cases, and specific mutations, such as H1047R in exon 20, may predict higher response rates to treatment with PI3K pathway inhibitors. ${ }^{55,56}$ In addition, PTEN mutations have been reported in $7 \%$ of HNSCC, and the mTOR pathway is frequently activated, independent from activation of EGFR or the presence of mutant p53, particularly in HPV-positive tumours. ${ }^{27,57}$

PI3K pathway is an important therapeutic target for cancers and its therapeutic modulation has been assessed in a number of tumour types. The mTOR inhibitor everolimus is in clinical use in renal cell carcinoma, pancreatic neuroendocrine tumours, breast cancer and subependymal giant cell astrocytoma, and temsirolimus can be used in renal cell carcinoma. PI3K inhibitors are being investigated in phase II trials in HNSCC in conjunction with chemotherapy or cetuximab (NCT01252628); AKT inhibitors are being tested in recurrent or metastatic nasopharyngeal cancer (NCT01349933); and the mTOR inhibitors rapamycin, everolimus and temsirolimus are being assessed for HNSCC at the phase II stage in neoadjuvant and recurrent/metastatic settings.

\section{Ras/Raf/MEK/MAPK Pathway}

Ras is a guanosine nucleotide binding protein localised on the plasma membrane. There are three Ras genes: HRAS, KRAS and NRAS. In the inactivated state, Ras is bound to guanosine diphosphate (GDP) and activation converts Ras to the guanosine triphosphate (GTP)-bound form; Ras-GTP binds to and activates Raf-1. The targets for phosphorylation of Raf-1 include the kinases MEK1 and MEK2 that in turn activate the MAP kinases ERK1 and ERK2. These translocate to the nucleus and target genes involved in cell growth, proliferation and survival. Ras can also activate the PI3K signalling cascade. ${ }^{58}$

Mutations in the Ras proto-oncogenes are implicated in $20-30 \%$ of all cancers. ${ }^{58}$ Activating HRAS mutations have been found in $4-5 \%$ of HNSCC cases. ${ }^{20,27}$ KRAS mutations occur in $30-50 \%$ of colorectal cancers and are predictive of poor response to panitumumab and cetuximab. ${ }^{59}$ 
The predictive value of KRAS in HNSCC remains unclear and requires further investigation.

Sorafenib is a tyrosine kinase inhibitor that has multiple targets including Raf, VEGF (vascular endothelial growth factor receptor) and PDGFR (platelet-derived growth factor receptor). ${ }^{60}$ It is in use in renal cell carcinoma and hepatocellular carcinoma, but has poor results as a single agent in HNSCC. Sorafenib in combination with chemotherapy has shown a response rate of $55 \%$ and median overall survival of 22.6 months in a phase II trial in HNSCC. ${ }^{61}$ The MEK inhibitor trametinib has recently been approved for use in metastatic melanoma and is under investigation in combination with AKT inhibition in solid tumours including HNSCC (NCT01725100).

\section{MET Pathway}

The proto-oncogene $c-M E T$ encodes mesenchymalepithelial transition factor (MET), an RTK activated by hepatocyte growth factor (HGF). Ligand binging activates signalling cascades including the RAS, PI3K, STAT3 and $\mathrm{NOTCH}$ pathways, resulting in cell morphogenesis, motility, growth and survival. MET and HGF have been found to be overexpressed in over $80 \%$ of HNSCC and increased MET copy numbers in $13 \%$ of HNSCC tumour samples. ${ }^{62,63}$ MET expression has been suggested to be a prognostic biomarker in HPV-negative HNSCC with overexpression correlating with reduced disease-free and overall survival. ${ }^{64,65}$ It has also been implicated in resistance to radiation, cisplatin and cetuximab. ${ }^{66-68}$

MET overexpression results in enhanced cell motility, angiogenesis and invasion/metastases, and therefore is an important potential therapeutic target. Foretinib is a multityrosine kinase inhibitor that binds to the adenosine triphosphate (ATP) pocket of the receptor. It has been tested in a phase II study in recurrent/metastatic HNSCC but showed disease stabilisation and only minor tumour shrinkage as a single agent. ${ }^{69}$ There are several RTK inhibitors and mAbs against MET and HGF in early phase clinical trials.

\section{JAK/STAT Pathway}

The JAKs are part of a family of nonreceptor tyrosine kinases. They interact with the cell surface cytokine receptors and activate them by transphosphorylation. Activated cytokine receptors recruit STAT that is phosphorylated by JAKs, mediating dimerisation and translocation to the nucleus to activate transcription of their target genes. JAKs can also be phosphorylated directly by RTKs such as EGFR, activating the RAS and PI3K pathways. The JAK/STAT pathway has a role in promoting cell growth and survival, angiogenesis and suppression of immune surveillance. ${ }^{70}$

STAT proteins are important in mediating EGFR signalling and STAT3 is overexpressed in HNSCC. ${ }^{71}$ Ruxolitinib is a JAK inhibitor approved for use in myelofibrosis and is in phase I studies in combination with chemotherapy in advanced solid tumours. A phase 0 trial of a STAT decoy oligonucleotide injected into HNSCC tumours before surgery demonstrated downregulation of STAT3 target gene expression, warranting further investigation of this target in $\mathrm{HNSCC}^{72}$

\section{HPV-Mediated Pathogenesis}

HPVs are small, nonenveloped, double-stranded DNA viruses. The genome encodes for early genes (E1-7) and late structural genes (L1, L2). E1 and E2 encode regulatory proteins and E5-7 encode oncoproteins. Over 100 human HPV genotypes have been isolated, and mucosal HPVs can be classified into high and low risk based on their potential to induce malignant transformation. High-risk HPVs include types 16, 18, 31 and 33, with HPV type 16 accounting for over $90 \%$ of cases in HNSCC. ${ }^{73}$ HPVs enter the host via wounds or abrasions in the mucosa and infect basal epithelial cells, where the host cell DNA replication machinery is used for viral replication. The basal cell nuclei maintain low copy numbers of viral DNA, whereas the virus replicates to high copy numbers in terminally differentiated cells. ${ }^{74}$ The E6 protein interacts with E6-associated protein (E6-AP), resulting in a rapid degradation of tumour suppressor p53 via the ubiquitin-proteosome pathway (Figure 3). This leads to inhibition of the proapoptotic functions of p53 and bypassing of the p53-mediated checkpoints. ${ }^{75}$ The E7 protein competes with E2F transcription factor for binding to the $\mathrm{pRb}$ tumour suppressor, displacing E2F. E2F activates genes responsible for cell cycle progression through the $G_{1}$ to $S$ phase, including cyclin $A, E$ and DNA polymerase, causing inactivation of checkpoints and regulatory pathways, and ultimately promoting cellular proliferation and transformation (Figure 3). ${ }^{76} \mathrm{pRb}$ is a negative regulator of the cyclin-dependent kinase inhibitor $\mathrm{p} 16$, and therefore inactivation of $\mathrm{pRb}$ results in $\mathrm{p} 16$ upregulation. This can be detected using immunohistochemistry in HPV-associated tumour samples and represents a biologically significant surrogate marker for HPV oncoprotein expression. ${ }^{77}$

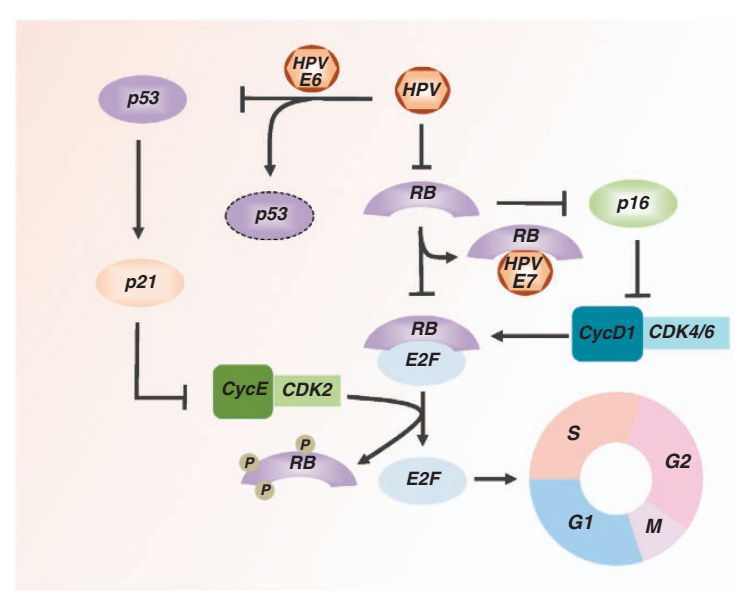

Figure 3 Mechanism of action of the human papillomavirus (HPV) on cell cycle regulation. To progress from $\mathrm{G} 1$ to $S$ cell cycle phase, cells have to pass the $\mathrm{G} 1$ restriction point that is under the control of the retinoblastoma protein $(p R b) . p R b$ binds and represses E2F transcriptional factors. Mitogenic signalling through CyclinD1/CDK4 or CyclinD1/CDK6 phosphorylates pRb, promoting E2F release. CyclinE/CDK2 completes pRb phosphorylation, allowing S-phase entry. HPV affects the cell cycle by using two viral oncoproteins, E6 and E7. The E6 protein binds p53 and promotes its degradation, whereas E7 protein binds and inactivates $\mathrm{pRb}$. These viral oncoproteins determine cell cycle entry and inhibition of p53mediated apoptosis. HPV-dependent inhibition of pRb promotes $\mathrm{p} 16$ accumulation. p16 represents a surrogate marker of HPV-positive HNSCC 
Table 2 Clinical features of HPV-positive and -negative HNSCC

\begin{tabular}{lllc}
\hline & HPV negative & HPV positive & References \\
\hline Aetiology & Tobacco/alcohol & HPV infection & $2,5,78$ \\
Age & Above 60 years & Below 60 years & 5 \\
p53 mutations & Highly frequent & Infrequent & 20,27 \\
Site & Not predictable & Oropharynx & 78 \\
Prognosis & Poor & Favourable & 77,87 \\
\hline
\end{tabular}

HPV infection in oropharyngeal cancer is now recognised as an aetiological agent, responsible for the significant increase in incidence in Western countries (Table 2)..$^{5,78}$ These cancers represent a distinct subgroup characterised by specific biological and clinical profiles and improved outcomes. Patients with HPV-associated oropharyngeal squamous cell carcinoma (OPSCC) tend to be white males, on average 5 years younger than HPV-negative patients, have higher socioeconomic status and are less likely to smoke or drink alcohol. ${ }^{4}$ Risk factors for HPV-positive HNSCC are related to sexual behaviour, including young age at first intercourse and high number of sexual partners, in particular oral sex partners, and antibodies against HPV16 viral capsid protein and E6 oncoprotein. ${ }^{79-82}$ Clinically, these tumours have been found to be present at an earlier stage of the primary cancer but with cystic, multilevel nodal metastases. ${ }^{83,84}$ Histologically, the tumours tend to be poorly differentiated basaloid (or nonkeratinising squamous cell) carcinomas. ${ }^{85} \mathrm{HPV}$ is detected in other subsites such as larynx and nasopharynx but no causal relationship or association with outcome has been established, and therefore the significance in nonoropharyngeal head and neck tumours remains unclear. ${ }^{86}$

HPV-associated OPSCC has a favourable prognosis. Compared with HPV-negative OPSCC, patients have a $60-80 \%$ reduction in the risk of death from their cancer after controlling for other factors, highlighting the need for different treatment strategies to reduce the morbidity associated with current treatment. ${ }^{77,78}$ The reasons for the improved outcome are unclear but possibilities include host factors such as younger age, fewer smoking-related comorbidities and tumour factors such as increased sensitivity to radiotherapy, absence of field cancerisation mainly seen in smokers, differing response of the host immune system to viral infection, and the presence of wild-type p53 that may become activated in response to radiotherapy and chemotherapy. However, not all HPV-positive patients have the same excellent outcome and they can be further classified into low and intermediate risk of death categories depending on their smoking history. ${ }^{87}$ HPV-negative HNSCC are typically characterised by TP53 and RB genetic alterations resulting in genomic instability and resistance to apoptosis. No TP53 mutations were seen in HPV-positive HNSCC on exome sequencing, and the overall mutation rate was approximately half of that seen in HPV-negative samples. In addition, in contrast to HPV-negative tumours, the expression of $C D K N 2 A$, encoding $\mathrm{p} 16^{\mathrm{INK} 4 \mathrm{~A}}$, is highly upregulated and amplification of cyclin D is infrequent. ${ }^{88}$

At present, treatment is the same regardless of HPV status outside the context of a clinical trial. Two phase III studies currently recruiting (De-ESCaLATE HPV and RTOG 1016) are investigating the replacement of standard cisplatin in concomitant chemoradiation with cetuximab, on the basis that cetuximab may be less toxic with comparable results in retrospective analyses. ${ }^{89}$ The results of two studies treating HPV-positive patients with induction chemotherapy followed by reduced dose radiation in responders are awaited. HPV vaccines are under development and investigation, as both preventative and therapeutic applications. Gardasil and Cervarix are HPV vaccines in use for the prevention of cervical cancer, but could afford protection against oral HPV16/18 infection. Reduced prevalence of oral HPV infection was found in women recruited to investigate the efficacy of HPV vaccination against cervical cancer. ${ }^{90}$ These vaccines may also cause induction of cell-mediated immunity against HPV-positive tumours, and phase I studies are ongoing investigating the use of HPV16 peptide epitopes in recurrent disease. ${ }^{91}$

\section{Hypoxia and Angiogenesis}

Tumour hypoxia is common in HNSCC and is associated with treatment resistance and reduced survival. ${ }^{92}$ Under normoxia, the hypoxia-inducible factors HIF1- $\alpha$ and HIF2- $\alpha$ are rapidly degraded by the Von Hippel-Lindau protein (VHL). Hypoxia leads to stabilisation of HIFs that heterodimerise with constitutively expressed HIF2 $\beta$ and translocate to the nucleus. Genes that promote survival in hypoxia, including carbonic anhydrase 9 (CA9), glucose transporter 1 (GLUT1) and vascular endothelial growth factor (VEGF), are upregulated. HIF2- $\alpha$ mediates activation of EGFR, and HIF activation is partly regulated by mTOR signalling. ${ }^{93}$ Hypoxia can also drive genomic instability in tumour cells and select for cell populations with a more aggressive phenotype, reduced apoptotic and increased metastatic potential. ${ }^{94}$

Oxygen is required for effective radiation-induced cell damage, as oxygen stabilises the free radicals produced by ionising radiation that causes DNA damage and cell death. ${ }^{95}$ To improve their nutrient and oxygen supply, tumours produce angiogenic factors that induce the proliferation of endothelial cells and form new blood vessels. VEGF is the strongest inducer of angiogenesis, and immunohistochemical expression in tumour samples is associated with an increased risk of death. ${ }^{96}$

Strategies to improve tumour oxygenation have included the use of hyperbaric oxygen, carbogen and nicotinamide, radiosensitisation using nitroimidazoles and the hypoxic cytotoxin tirapazamine. However, because of the difficulties in measuring and stratifying for hypoxia, these techniques have not translated into regular clinical practice. ${ }^{95}$ There is therefore interest in developing methods to diagnose hypoxia and predict the response to hypoxia-modifying treatments. For example, a 15-gene hypoxia classifier applied retrospectively to HNSCC tissue samples was found to predict for hypoxic modification of radiotherapy with the radiosensitiser nimorazole. ${ }^{97}$ More recently, a 26-gene hypoxia signature showed predictive benefit from hypoxia-modifying agents carbogen and nicotinamide in combination with accelerated radiotherapy. ${ }^{98}$ Prospective application and validation of these signatures are awaited. The VEGFR-targeting therapies are currently under investigation in HNSCC. 
Bevacizumab, a monocloncal antibody against VEGFR, is in clinical use in metastatic colorectal and breast cancer, NSCLC, glioblastoma and renal cell carcinoma. Phase II studies in HNSCC using bevacizumab in combination with pemetrexed, erlotinib or cetuximab have shown response rates of $15-30 \% .^{99-101}$ The multiple tyrosine kinase inhibitors sunitinib, sorafenib and vandetanib are in clinical use, and sorafenib has shown promise in combination with chemotherapy in recurrent/metastatic HNSCC (Table 1).

\section{Metabolism}

Energy in the form of ATP is generated in normal cells via glycolysis or the tricarboxylic acid (TCA) cycle. In glycolysis, glucose is metabolised to pyruvate in the cytosol to produce two ATPs from each molecule of glucose. The TCA cycle utilises pyruvate from glycolysis to produce acetyl-CoA that is catalysed by pyruvate dehydrogenase (PDH) in the mitochondria. Acetyl-CoA is metabolised by oxidative phosphorylation, consuming oxygen and generating 36 ATPs per glucose. In anaerobic conditions, pyruvate is not used in the TCA cycle and is converted to lactate in the cytosol by lactate dehydrogenase (LDH). ${ }^{102}$

Metabolic alterations are common in cancer. The bestcharacterised metabolic phenotype was originally described by Warburg et al. ${ }^{103}$ in the 1920 s. The Warburg effect is the increase in glycolysis to generate ATP, even in the presence of normal oxygen concentrations. ATP production via glycolysis is much faster but less efficient than oxidative phosphorylation, and cancer cells avidly consume glucose to meet their increased energy and biosynthesis needs. ${ }^{104}$ Aerobic glycolysis in tumour cells is regulated by aberrant signalling pathways, including p53, PI3K, HIF1, MYC ${ }^{105-107}$ and liver kinase B1 (LKB1)/AMP-activated protein kinase (AMPK) pathways, ${ }^{108}$ as well as alterations in metabolic enzymes, such as pyruvate kinase and pyruvate dehydrogenase kinase (PDK). ${ }^{109}$

Aberrant metabolism can be targeted by inhibiting the AKT and mTOR pathways as previously discussed. PDK inhibition with dichloroacetate is being explored in a phase I trial of metabolic reprogramming therapy in recurrent HNSCC (NCT01163487). Metformin is currently used in type II diabetes but also acts as an AMPK activator. Diabetic patients treated with metformin were found to be at lower risk of developing cancer than those on other treatments. ${ }^{110}$ Metformin in combination with paclitaxel is being investigated in a phase II trial in metastatic/recurrent HNSCC (NCT01333852).

\section{HNSCC Cancer Stem Cells}

HNSCC is highly heterogeneous. This heterogeneity was originally thought to be because of the step-wise accumulation of specific genetic and epigenetic alterations in response to carcinogens, resulting in preneoplastic fields. Clonal divergence and selection within these fields leads to the development of cancer, and the incomplete eradication of these areas are the source of recurrence and secondary tumours after treatment. ${ }^{111}$ However, accumulating evidence supports an alternative model for the development and progression of HNSCC involving cancer stem cells (CSCs). This model describes the existence of a hierarchy of cells, where CSCs are a subpopulation within the tumour, capable of initiating and propagating tumourigenesis. These cells have the ability of self-renewal, maintaining the CSC reservoir and differentiate into the heterogeneous progeny. ${ }^{112}$ CSCs have been implicated in resistance to treatment, as they are nondividing or slowly dividing, evading the conventional chemotherapy and radiotherapy strategies that target rapidly diving cells. ${ }^{113}$ However, they have the potential to become activated resulting in recurrences or metastases.

CD44 is a transmembrane glycoprotein that acts as a receptor for hyaluronic acid and other extracellular matrix molecules, and is involved in cell adhesion and migration. Alternative splicing results in multiple different CD44 variants with a diverse functional repertoire. ${ }^{114}$ HNSCC CSCs were first described based on CD44 expression. ${ }^{115}$ CD44 + HNSCC cells, but not CD44 - cells, initiated tumourigenesis in mice, reproduced the original tumour heterogeneity and demonstrated self-renewal after serial passaging in vivo. ${ }^{115} \mathrm{CD} 44+$ cells were also found to differentially express the $B M I-1$ gene, ${ }^{115}$ encoding a self-renewal protein found in embryonic stem cells. ${ }^{116}$ However, expression of CD44 has also been observed diffusely in normal, benign and malignant epithelia of the head and neck, suggesting CD44 alone cannot identify CSCs. ${ }^{117}$

Aldehyde dehydrogenase (ALDH) is an enzyme involved in detoxifying intracellular aldehydes by oxidation, and converting retinol to retinoic acid. ${ }^{118}$ It has been shown that ALDH + and CD44 + cells form a subpopulation of cells that are highly tumourigenic in immunodeficient mice at very low cell numbers, as well as the ability to self-renew. ${ }^{119}$ Therefore, the combination of these two markers are more selective for CSCs. ALDH1 + CD44 + cells have also demonstrated increased expression of BMI- $1,{ }^{119}$ resistance to chemoradiation and involvement in epithelial-mesenchymal transition. ${ }^{120}$

CSCs represent potential novel diagnostic and therapeutic targets. The concentration of CD44 in the peripheral blood of HNSCC patients has been shown to be significantly higher than healthy controls, ${ }^{121}$ and increased CD44 + cell population in the primary tumour correlates with higher rates of recurrence. ${ }^{122}$ In addition, CD44 gene expression levels have been found to correlate with response to radiotherapy in laryngeal SCC, suggesting its role as a predictive marker. ${ }^{123}$ Targeted elimination of cancer stem cells directly or via their niche, for example, with antiangiogenic agents, are potential treatment strategies under development. Bivatuzumab mertansine, an anti-microtubule agent coupled to a monoclonal antibody against CD44 variant 6 , has been tested in metastatic HNSCC. However, two parallel phase I studies were terminated early after a fatal case of toxic epidermal necrolysis. ${ }^{124}$ Further investigation is required to fully understand the potential effects of targeting CSCs in HNSCC.

\section{Gene and MicroRNA Expression in HNSCC}

There has been a multitude of published studies investigating gene expression profiling to diagnose HNSCC and predict behaviour and sensitivity to treatment. ${ }^{125-127}$ The detailed analysis of such studies is beyond the scope of this review; in general, because of tumour heterogeneity and low case numbers in some studies, these studies have not been 
Table 3 MicroRNAs in HNSCC

\begin{tabular}{lll}
\hline MicroRNA & Targets & Function \\
\hline $\begin{array}{l}\text { Upregulated } \\
\text { miR-21 } \\
\text { miR-106b }\end{array}$ & PTEN, PCDC4 & \\
miR-205 & p21 & Cell cycle progression, metastasis \\
miR-181 & PTEN & Cell cycle progression \\
miR-211 & not reported in HNSCC & Prognostic marker, metastasis \\
& not reported in HNSCC & Prognostic factor, metastasis \\
$\begin{array}{l}\text { Downregulated } \\
\text { let-7 }\end{array}$ & & Prognostic factor, metastasis \\
miR-133a/b & KRAS & \\
miR-200a & PKM2, ARPC5 & Prognostic marker, metastasis \\
& ZEB1, ZEB2 & Cancer metabolism \\
\end{tabular}

conclusive. Larger and heterogeneous patient cohorts are therefore needed to obtain an mRNA signature that can be utilised in a clinical setting.

MicroRNAs (miRNAs) are endogenous, small, non-coding RNAs of 18-25 nucleotides that regulate and refine gene expression at both transcriptional and translational levels. Over 1000 miRNAs have so far been identified, with each miRNA influencing the expression of multiple genes and a single mRNA being targeted by several miRNAs. They are involved in the fine-tuning of the expression of many genes involved in a variety of critical biological processes, including cell cycle regulation, differentiation, metabolism and death (Table 3). ${ }^{128}$ Consistently altered miRNAs in HNSCC include miR-21 that is negatively correlated with PTEN and the programmed cell death $4(P D C D 4)$ gene and implicated in cell proliferation, invasion and metastases; ${ }^{129}$ the miR-106b family that negatively regulates the p21 CDK inhibitor; ${ }^{130}$ and miR-205 that targets PTEN and is suggested as a potential maker for diagnosis, lymph mode metastasis and outcome. $^{131,132}$ The ratio of miR-221 to miR-375 can distinguish between normal and malignant tissue, ${ }^{133}$ and high expression of miR-181 and miR-211 in oral SCC has been found to be associated with lymph node metastases, vascular invasion and poor outcome. ${ }^{134,135}$ Tumour-suppressive miRNAs include let-7 that negatively regulates KRAS, and reduced expression is associated with poor prognosis. ${ }^{131,136}$ $\mathrm{MiR}-133 \mathrm{a} / \mathrm{b}$ is repeatedly reported to be downregulated in HNSCC and targets pyruvate kinase M2, a key regulator of cancer metabolism. ${ }^{137} \mathrm{MiR}-133 \mathrm{a}$ also directly regulates the actin-related protein complex 5 (ARPC5) with inhibition of cell migration and invasion when miR-133a is restored or ARPC5 is repressed. ${ }^{138}$ Downregulation of the tumour-suppressive miR-200a is seen in both saliva and tissue samples of HNSCC patients and is known to target ZEB1 and ZEB2 that repress the transcription of $E$-cadherin and mediate epithelialmesenchymal transition and tumour cell migration. ${ }^{139}$ MiRNAs are also implicated in chemoresistance, with different patterns of expression in resistant HNSCC. ${ }^{140}$ Modulation of miRNAs can alter the sensitivity of HNSCC to both drugs and radiation, highlighting the potential for miRNAs in predicting response to treatment and as a therapeutic target.

\section{Conclusion}

HNSCC is a group of highly heterogeneous tumours. Their management is likely to change in the near future, moving from treatment as a single disease to tailoring the therapy based on both patient and tumour characteristics. Identification of specific genetic, epigenetic and metabolic aberrations, together with the more traditional techniques in diagnosis, staging and prognostication, will need to inform the individual treatment strategy. It has the potential to provide the clinician with a comprehensive set of diagnostic, prognostic and predictive tools. The paucity of driver mutations in HNSCC and frequent tumour suppressor loss represents a pharmacological challenge, but increased understanding of the molecular biology through the developments in high-throughput technology heralds a future of personalised medicine.

\section{Conflict of Interest}

The authors declare no conflict of interest.

Acknowledgements. We thank King's Health Partners, King's College London and the Rosetrees Trust for supporting Dr. Yae-eun Suh. We also thank Mrs. Kathy Doyle for help in the preparation and submission of the manuscript.

1. Ferlay J, Shin HR, Bray F, Forman D, Mathers C, Parkin DM. Estimates of worldwide burden of cancer in 2008: GLOBOCAN 2008. Int J Cancer 2010; 127: 2893-2917.

2. Hashibe M, Brennan P, Benhamou S, Castellsague X, Chen C, Curado MP et al. Alcohol drinking in never users of tobacco, cigarette smoking in never drinkers, and the risk of head and neck cancer: pooled analysis in the International Head and Neck Cancer Epidemiology Consortium. J Natl Cancer Inst 2007; 99: 777-789.

3. Hashibe M, Brennan P, Chuang SC, Boccia S, Castellsague X, Chen C et al. Interaction between tobacco and alcohol use and the risk of head and neck cancer: pooled analysis in the International Head and Neck Cancer Epidemiology Consortium. Cancer Epidemiol Biomarkers Prev 2009; 18: 541-550.

4. Chaturvedi AK, Anderson WF, Lortet-Tieulent J, Curado MP, Ferlay J, Franceschi S et al. Worldwide Trends in incidence rates for oral cavity and oropharyngeal cancers. J Clin Oncol 2013; 31: 4550-4559.

5. Chaturvedi AK, Engels EA, Anderson WF, Gillison ML. Incidence trends for human papillomavirus-related and -unrelated oral squamous cell carcinomas in the United States. J Clin Oncol 2008; 26: 612-619.

6. Argiris A, Karamouzis MV, Raben D, Ferris RL. Head and neck cancer. Lancet 2008; 371 : 1695-1709.

7. Pignon JP, le Maitre A, Maillard E, Bourhis J. Group M-NC.. Meta-analysis of chemotherapy in head and neck cancer (MACH-NC): an update on 93 randomised trials and 17,346 patients. Radiother Oncol 2009; 92: 4-14.

8. Brockstein BE. Management of recurrent head and neck cancer: recent progress and future directions. Drugs 2011; 71: 1551-1559.

9. Walter V, Yin X, Wilkerson MD, Cabanski CR, Zhao N, Du Y et al. Molecular subtypes in head and neck cancer exhibit distinct patterns of chromosomal gain and loss of canonical cancer genes. PLoS One 2013; 8: e56823.

10. Vogelstein B, Lane D, Levine AJ. Surfing the p53 network. Nature 2000; 408: 307-310.

11. Brady CA, Jiang D, Mello SS, Johnson TM, Jarvis LA, Kozak MM et al. Distinct p53 transcriptional programs dictate acute DNA-damage responses and tumor suppression. Cell 2011; 145: 571-583. 
12. Kibe R, Zhang S, Guo D, Marrero L, Tsien F, Rodriguez P et al. IL-7Ralpha deficiency in p53null mice exacerbates thymocyte telomere erosion and lymphomagenesis. Cell Death Differ 2012; 19: 1139-1151.

13. Boren J, Brindle KM. Apoptosis-induced mitochondrial dysfunction causes cytoplasmic lipid droplet formation. Cell Death Differ 2012; 19: 1561-1570.

14. Leonova KI, Brodsky L, Lipchick B, Pal M, Novototskaya L, Chenchik AA et al. p53 cooperates with DNA methylation and a suicidal interferon response to maintain epigenetic silencing of repeats and noncoding RNAs. Proc Natl Acad Sci USA 2013; 110: E89-E98.

15. Cho JH, Kim MJ, Kim KJ, Kim JR. POZ/BTB and AT-hook-containing zinc finger protein 1 (PATZ1) inhibits endothelial cell senescence through a p53 dependent pathway. Cell Death Differ 2012; 19: 703-712.

16. Polager S, Ginsberg D. p53 and E2f: partners in life and death. Nat Rev Cancer 2009; 9 738-748.

17. Sherr CJ, McCormick F. The RB and p53 pathways in cancer. Cancer Cell 2002; 2: 103-112.

18. Allocati N, Di llio C, De Laurenzi V. p63/p73 in the control of cell cycle and cell death. Exp Cell Res 2012; 318: 1285-1290.

19. Morton JP, Timpson P, Karim SA, Ridgway RA, Athineos D, Doyle B et al. Mutant p53 drives metastasis and overcomes growth arrest/senescence in pancreatic cancer. Proc Natl Acad Sci USA 2010; 107: 246-251.

20. Agrawal N, Frederick MJ, Pickering CR, Bettegowda C, Chang K, Li RJ et al. Exome sequencing of head and neck squamous cell carcinoma reveals inactivating mutations in NOTCH1. Science 2011; 333: 1154-1157.

21. Poeta ML, Manola J, Goldwasser MA, Forastiere A, Benoit N, Califano JA et al. TP53 mutations and survival in squamous-cell carcinoma of the head and neck. $N$ Engl J Med 2007; 357: 2552-2561

22. Brennan JA, Mao L, Hruban RH, Boyle JO, Eby YJ, Koch WM et al. Molecular assessment of histopathological staging in squamous-cell carcinoma of the head and neck. N Engl J Med 1995; 332: 429-435.

23. Ebrahimi M, Boldrup L, Coates PJ, Wahlin YB, Bourdon JC, Nylander K. Expression of novel p53 isoforms in oral lichen planus. Oral Oncol 2008; 44: 156-161.

24. Kandoth C, McLellan MD, Vandin F, Ye K, Niu B, Lu C et al. Mutational landscape and significance across 12 major cancer types. Nature 2013; 502: 333-339.

25. Boyle JO, Hakim J, Koch W, van der Riet P, Hruban RH, Roa RA et al. The incidence of p53 mutations increases with progression of head and neck cancer. Cancer Res 1993 53: $4477-4480$

26. Brennan JA, Boyle JO, Koch WM, Goodman SN, Hruban RH, Eby YJ et al. Association between cigarette smoking and mutation of the p53 gene in squamous-cell carcinoma of the head and neck. N Engl J Med 1995; 332: 712-717.

27. Stransky N, Egloff AM, Tward AD, Kostic AD, Cibulskis K, Sivachenko A et al The mutational landscape of head and neck squamous cell carcinoma. Science 2011; 333: $1157-1160$

28. Smeets SJ, Braakhuis BJ, Abbas S, Snijders PJ, Ylstra B, van de Wiel MA et al. Genomewide DNA copy number alterations in head and neck squamous cell carcinomas with or without oncogene-expressing human papillomavirus. Oncogene 2006; 25: 2558-2564.

29. Bova RJ, Quinn DI, Nankervis JS, Cole IE, Sheridan BF, Jensen MJ et al. Cyclin D1 and p16INK4A expression predict reduced survival in carcinoma of the anterior tongue. Clin Cancer Res 1999; 5: 2810-2819.

30. Cabelguenne A, Blons H, de Waziers I, Carnot F, Houllier AM, Soussi T et al. p53 alterations predict tumor response to neoadjuvant chemotherapy in head and neck squamous cell carcinoma: a prospective series. J Clin Oncol 2000; 18: 1465-1473.

31. Koch WM, Brennan JA, Zahurak M, Goodman SN, Westra WH, Schwab D et al. p53 mutation and locoregional treatment failure in head and neck squamous cell carcinoma. J Natl Cancer Inst 1996; 88: 1580-1586.

32. Nemunaitis J, Clayman G, Agarwala SS, Hrushesky W, Wells JR, Moore C et al. Biomarkers predict p53 gene therapy efficacy in recurrent squamous cell carcinoma of the head and neck. Clin Cancer Res 2009; 15: 7719-7725.

33. Roh JL, Kang SK, Minn I, Califano JA, Sidransky D, Koch WM. p53-Reactivating small molecules induce apoptosis and enhance chemotherapeutic cytotoxicity in head and neck squamous cell carcinoma. Oral Oncol 2011; 47: 8-15.

34. Hynes NE, Lane HA. ERBB receptors and cancer: the complexity of targeted inhibitors. Nat Rev Cancer 2005; 5: 341-354.

35. Lin SY, Makino K, Xia W, Matin A, Wen Y, Kwong KY et al. Nuclear localization of EGF receptor and its potential new role as a transcription factor. Nat Cell Biol 2001; 3 : 802-808.

36. Grandis JR, Tweardy DJ. Elevated levels of transforming growth factor alpha and epidermal growth factor receptor messenger RNA are early markers of carcinogenesis in head and neck cancer. Cancer Res 1993; 53: 3579-3584.

37. Loeffler-Ragg J, Witsch-Baumgartner M, Tzankov A, Hilbe W, Schwentner I, Sprinzl GM et al. Low incidence of mutations in EGFR kinase domain in Caucasian patients with head and neck squamous cell carcinoma. Eur J Cancer 2006; 42: 109-111.

38. Temam S, Kawaguchi H, El-Naggar AK, Jelinek J, Tang H, Liu DD et al. Epidermal growth factor receptor copy number alterations correlate with poor clinical outcome in patients with head and neck squamous cancer. J Clin Oncol 2007; 25: 2164-2170.

39. Sok JC, Coppelli FM, Thomas SM, Lango MN, Xi S, Hunt JL et al. Mutant epidermal growth factor receptor (EGFRvIII) contributes to head and neck cancer growth and resistance to EGFR targeting. Clin Cancer Res 2006; 12: 5064-5073.
40. Ang KK, Berkey BA, Tu X, Zhang HZ, Katz R, Hammond EH et al. Impact of epidermal growth factor receptor expression on survival and pattern of relapse in patients with advanced head and neck carcinoma. Cancer Res 2002; 62: 7350-7356.

41. Licitra L, Mesia R, Rivera F, Remenar E, Hitt R, Erfan J et al. Evaluation of EGFR gene copy number as a predictive biomarker for the efficacy of cetuximab in combination with chemotherapy in the first-line treatment of recurrent and/or metastatic squamous cell carcinoma of the head and neck: EXTREME study. Ann Oncol 2011; 22: 1078-1087.

42. Bonner JA, Harari PM, Giralt J, Azarnia N, Shin DM, Cohen RB et al. Radiotherapy plus cetuximab for squamous-cell carcinoma of the head and neck. N Engl J Med 2006; 354 : 567-578

43. Vermorken JB, Mesia R, Rivera F, Remenar E, Kawecki A, Rottey S et al. Platinum-based chemotherapy plus cetuximab in head and neck cancer. N Engl J Med 2008; 359: $1116-1127$

44. Burtness B, Goldwasser MA, Flood W, Mattar B, Forastiere AA. Eastern Cooperative Oncology G. Phase III randomized trial of cisplatin plus placebo compared with cisplatin plus cetuximab in metastatic/recurrent head and neck cancer: an Eastern Cooperative Oncology Group study. J Clin Oncol 2005; 23: 8646-8654.

45. Vermorken JB, Stohlmacher-Williams J, Davidenko I, Licitra L, Winquist E, Villanueva C et al Cisplatin and fluorouracil with or without panitumumab in patients with recurrent or metastatic squamous-cell carcinoma of the head and neck (SPECTRUM): an open-label phase 3 randomised trial. Lancet Oncol 2013; 14: 697-710.

46. Wheeler DL, Huang S, Kruser TJ, Nechrebecki MM, Armstrong EA, Benavente S et al. Mechanisms of acquired resistance to cetuximab: role of HER (ErbB) family members. Oncogene 2008; 27: 3944-3956.

47. Harrington K, Berrier A, Robinson M, Remenar E, Housset M, de Mendoza FH et al. Randomised Phase II study of oral lapatinib combined with chemoradiotherapy in patients with advanced squamous cell carcinoma of the head and neck: rationale for future randomised trials in human papilloma virus-negative disease. Eur J Cancer 2013; 49 1609-1618.

48. Egloff AM, Grandis JR. Molecular pathways: context-dependent approaches to Notch targeting as cancer therapy. Clin Cancer Res 2012; 18: 5188-5195.

49. Pickering CR, Zhang J, Yoo SY, Bengtsson L, Moorthy S, Neskey DM et al. Integrative genomic characterization of oral squamous cell carcinoma identifies frequent somatic drivers. Cancer discovery 2013; 3: 770-781.

50. Weng AP, Ferrando AA, Lee W, Morris JPt, Silverman LB, Sanchez-Irizarry C et al. Activating mutations of NOTCH1 in human T cell acute lymphoblastic leukemia. Science 2004; 306: 269-271.

51. Kolev V, Mandinova A, Guinea-Viniegra J, Hu B, Lefort K, Lambertini C et al. EGFR signalling as a negative regulator of Notch1 gene transcription and function in proliferating keratinocytes and cancer. Nat Cell Biol 2008; 10: 902-911.

52. Dotto GP. Crosstalk of Notch with $\mathrm{p} 53$ and $\mathrm{p} 63$ in cancer growth control. Nat Rev Cancer 2009; 9: 587-595

53. Talora C, Sgroi DC, Crum CP, Dotto GP. Specific down-modulation of Notch1 signaling in cervical cancer cells is required for sustained HPV-E6/E7 expression and late steps of malignant transformation. Genes Dev 2002; 16: 2252-2263.

54. Engelman JA. Targeting PI3K signalling in cancer: opportunities, challenges and limitations. Nat Rev Cancer 2009; 9: 550-562.

55. Janku F, Wheler JJ, Naing A, Falchook GS, Hong DS, Stepanek VM et al. PIK3CA mutation H1047R is associated with response to PI3K/AKT/mTOR signaling pathway inhibitors in early-phase clinical trials. Cancer Res 2013; 73: 276-284.

56. Qiu W, Schonleben F, Li X, Ho DJ, Close LG, Manolidis S et al. PIK3CA mutations in head and neck squamous cell carcinoma. Clin Cancer Res 2006; 12: 1441-1446.

57. Molinolo AA, Marsh C, El Dinali M, Gangane N, Jennison K, Hewitt S et al. mTOR as a molecular target in HPV-associated oral and cervical squamous carcinomas. Clin Cance Res 2012; 18: 2558-2568.

58. Bos JL. ras oncogenes in human cancer: a review. Cancer Res 1989; 49: 4682-4689.

59. Bardelli A, Siena S. Molecular mechanisms of resistance to cetuximab and panitumumab in colorectal cancer. J Clin Oncol 2010; 28: 1254-1261.

60. Wilhelm SM, Adnane L, Newell P, Villanueva A, Llovet JM, Lynch M. Preclinical overview of sorafenib, a multikinase inhibitor that targets both Raf and VEGF and PDGF receptor tyrosine kinase signaling. Mol Cancer Ther 2008; 7: 3129-3140.

61. Blumenschein GR Jr, Glisson BS, Lu C, Sabichi AL, Ginsberg LE, Bartos Cl et al. Final results of a phase II study of sorafenib in combination with carboplatin and paclitaxel in patients with metastatic or recurrent SCCHN. J Clin Oncol 2012; 30(Suppl): abstract 5592.

62. Knowles LM, Stabile LP, Egloff AM, Rothstein ME, Thomas SM, Gubish CT et al. HGF and c-Met participate in paracrine tumorigenic pathways in head and neck squamous cell cancer. Clin Cancer Res 2009; 15: 3740-3750.

63. Seiwert TY, Jagadeeswaran R, Faoro L, Janamanchi V, Nallasura V, El Dinali M et al. The MET receptor tyrosine kinase is a potential novel therapeutic target for head and neck squamous cell carcinoma. Cancer Res 2009; 69: 3021-3031.

64. Zhao D, Wang SH, Feng Y, Hua CG, Zhao J, Tang XF. Intratumoral c-Met expression is associated with vascular endothelial growth factor $\mathrm{C}$ expression, lymphangiogenesis, and lymph node metastasis in oral squamous cell carcinoma: implications for use as a prognostic marker. Hum Pathol 2011; 42: 1514-1523.

65. Lo Muzio L, Farina A, Rubini C, Coccia E, Capogreco M, Colella G et al. Effect of c-Met expression on survival in head and neck squamous cell carcinoma. Tumour Biol 2006; 27 $115-121$. 
66. De Bacco F, Luraghi P, Medico E, Reato G, Girolami F, Perera T et al. Induction of MET by ionizing radiation and its role in radioresistance and invasive growth of cancer. $J$ Nat Cancer Inst 2011; 103: 645-661.

67. Sun S, Wang Z. Head neck squamous cell carcinoma c-Met $(+)$ cells display cancer stem cell properties and are responsible for cisplatin-resistance and metastasis. Int $\mathrm{J}$ Cancer 2011; 129: 2337-2348.

68. Krumbach R, Schuler J, Hofmann M, Giesemann T, Fiebig HH, Beckers T. Primary resistance to cetuximab in a panel of patient-derived tumour xenograft models: activation of MET as one mechanism for drug resistance. Eur J Cancer 2011; 47 1231-1243.

69. Seiwert T, Sarantopoulos J, Kallender H, McCallum S, Keer HN, Blumenschein G Jr. Phase II trial of single-agent foretinib (GSK1363089) in patients with recurrent or metastatic squamous cell carcinoma of the head and neck. Invest New Drugs 2013; 31: 417-424

70. Aaronson DS, Horvath CM. A road map for those who don't know JAK-STAT. Science 2002; 296: 1653-1655.

71. Grandis JR, Drenning SD, Zeng Q, Watkins SC, Melhem MF, Endo S et al. Constitutive activation of Stat3 signaling abrogates apoptosis in squamous cell carcinogenesis in vivo. Proc Natl Acad Sci USA 2000; 97: 4227-4232.

72. Sen M, Thomas SM, Kim S, Yeh JI, Ferris RL, Johnson JT et al. First-in-human trial of a STAT3 decoy oligonucleotide in head and neck tumors: implications for cancer therapy. Cancer Discov 2012; 2: 694-705.

73. Kreimer AR, Clifford GM, Boyle P, Franceschi S. Human papillomavirus types in head and neck squamous cell carcinomas worldwide: a systematic review. Cancer Epidemio Biomark Prev 2005; 14: 467-475.

74. Giroglou T, Florin L, Schafer F, Streeck RE, Sapp M. Human papillomavirus infection requires cell surface heparan sulfate. J Virol 2001; 75: 1565-1570.

75. Scheffner M, Werness BA, Huibregtse JM, Levine AJ, Howley PM. The E6 oncoprotein encoded by human papillomavirus types 16 and 18 promotes the degradation of p53. Cell 1990; 63: 1129-1136.

76. Dyson N, Howley PM, Munger K, Harlow E. The human papilloma virus-16 E7 oncoprotein is able to bind to the retinoblastoma gene product. Science 1989; 243 934-937.

77. Weinberger PM, Yu Z, Haffty BG, Kowalski D, Harigopal M, Brandsma J et al. Molecular classification identifies a subset of human papillomavirus-associated oropharyngeal cancers with favorable prognosis. J Clin Oncol 2006; 24: 736-747.

78. Gillison ML, Koch WM, Capone RB, Spafford M, Westra WH, Wu L et al. Evidence for a causal association between human papillomavirus and a subset of head and neck cancers. J Natl Cancer Inst 2000; 92: 709-720.

79. Gillison ML, D'Souza G, Westra W, Sugar E, Xiao W, Begum S et al. Distinct risk factor profiles for human papillomavirus type 16-positive and human papillomavirus type 16-negative head and neck cancers. J Natl Cancer Inst 2008; 100: 407-420.

80. Kreimer AR, Johansson M, Waterboer T, Kaaks R, Chang-Claude J, Drogen D et al. Evaluation of human papillomavirus antibodies and risk of subsequent head and neck cancer. J Clin Oncol 2013; 31: 2708-2715.

81. Mork J, Lie AK, Glattre E, Hallmans G, Jellum E, Koskela P et al. Human papillomavirus infection as a risk factor for squamous-cell carcinoma of the head and neck. $N$ Engl J Med 2001; 344: 1125-1131.

82. D'Souza G, Kreimer AR, Viscidi R, Pawlita M, Fakhry C, Koch WM et al. Case-control study of human papillomavirus and oropharyngeal cancer. N Engl J Med 2007; 356: 1944-1956.

83. Goldenberg D, Begum S, Westra WH, Khan Z, Sciubba J, Pai SI et al. Cystic lymph node metastasis in patients with head and neck cancer: an HPV-associated phenomenon. Head Neck 2008; 30: 898-903.

84. Rischin D, Young RJ, Fisher R, Fox SB, Le QT, Peters LJ et al. Prognostic significance of p16INK4A and human papillomavirus in patients with oropharyngeal cancer treated on TROG 02.02 phase III trial. J Clin Oncol 2010; 28: 4142-4148.

85. Begum S, Westra WH. Basaloid squamous cell carcinoma of the head and neck is a mixed variant that can be further resolved by HPV status. Am J Surg Pathol 2008; 32 1044-1050.

86. Isayeva T, Li Y, Maswahu D, Brandwein-Gensler M. Human papillomavirus in non-oropharyngeal head and neck cancers: a systematic literature review. Head Neck Pathol 2012; 6(Suppl 1): S104-S120.

87. Ang KK, Harris J, Wheeler R, Weber R, Rosenthal DI, Nguyen-Tan PF et al. Human papillomavirus and survival of patients with oropharyngeal cancer. N Engl J Med 2010; 363: 24-35.

88. Slebos RJ, Yi Y, Ely K, Carter J, Evjen A, Zhang X et al. Gene expression differences associated with human papillomavirus status in head and neck squamous cell carcinoma. Clin Cancer Res 2006; 12(3 Pt 1): 701-709.

89. Mehra $\mathrm{R}$, Cohen RB, Burtness $B A$. The role of cetuximab for the treatment of squamous cell carcinoma of the head and neck. Clin Adv Hematol Oncol 2008; 6: 742-750.

90. Herrero R, Quint W, Hildesheim A, Gonzalez P, Struijk L, Katki HA et al. Reduced prevalence of oral human papillomavirus (HPV) 4 years after bivalent HPV vaccination in a randomized clinical trial in Costa Rica. PLoS One 2013; 8: e68329.

91. Fung $\mathrm{C}$, Grandis JR. Emerging drugs to treat squamous cell carcinomas of the head and neck. Expert Opin Emerg Drugs 2010; 15: 355-373.
92. Nordsmark M, Bentzen SM, Rudat V, Brizel D, Lartigau E, Stadler P et al. Prognostic value of tumor oxygenation in 397 head and neck tumors after primary radiation therapy. An international multi-center study. Radiother Oncol 2005; 77: 18-24.

93. Haase VH. The VHL tumor suppressor: master regulator of HIF. Curr Pharm Des 2009; 15: 3895-3903

94. Hockel M, Vaupel P. Biological consequences of tumor hypoxia. Semin Oncol 2001; 28(2 Suppl 8): 36-41.

95. Overgaard J. Hypoxic radiosensitization: adored and ignored. J Clin Oncol 2007; 25: 4066-4074.

96. Kyzas PA, Cunha IW, loannidis JP. Prognostic significance of vascular endothelial growth factor immunohistochemical expression in head and neck squamous cell carcinoma: a meta-analysis. Clin Cancer Res 2005; 11: 1434-1440.

97. Toustrup K, Sorensen BS, Nordsmark M, Busk M, Wiuf C, Alsner J et al. Development of a hypoxia gene expression classifier with predictive impact for hypoxic modification of radiotherapy in head and neck cancer. Cancer Res 2011; 71: 5923-5931.

98. Eustace A, Mani N, Span PN, Irlam JJ, Taylor J, Betts GN et al. A 26-gene hypoxia signature predicts benefit from hypoxia-modifying therapy in laryngeal cancer but not bladder cancer. Clin Cancer Res 2013; 19: 4879-4888.

99. Argiris A, Kotsakis AP, Hoang T, Worden FP, Savvides P, Gibson MK et al. Cetuximab and bevacizumab: preclinical data and phase II trial in recurrent or metastatic squamous cell carcinoma of the head and neck. Ann Oncol 2013; 24: 220-225.

100. Argiris A, Karamouzis MV, Gooding WE, Branstetter BF, Zhong S, Raez LE et al. Phase I trial of pemetrexed and bevacizumab in patients with recurrent or metastatic head and neck cancer. J Clin Oncol 2011; 29: 1140-1145.

101. Cohen EE, Davis DW, Karrison TG, Seiwert TY, Wong SJ, Nattam S et al. Erlotinib and bevacizumab in patients with recurrent or metastatic squamous-cell carcinoma of the head and neck: a phase I/II study. Lancet Oncol 2009; 10: 247-257.

102. Kim JW, Dang CV. Cancer's molecular sweet tooth and the Warburg effect. Cancer Res 2006; 66: 8927-8930.

103. Warburg 0 , Wind F, Negelein E. The metabolism of tumors in the body. J Gen Physiol 1927; 8: 519-530

104. Cairns RA, Harris IS, Mak TW. Regulation of cancer cell metabolism. Nat Rev Cancer 2011; 11: 85-95.

105. Bensaad K, Tsuruta A, Selak MA, Vidal MN, Nakano K, Bartrons R et al. TIGAR, a p53-inducible regulator of glycolysis and apoptosis. Cell 2006; 126: 107-120.

106. Dang CV, Kim JW, Gao P, Yustein J. The interplay between MYC and HIF in cancer. Nat Rev Cancer 2008; 8: 51-56.

107. Elstrom RL, Bauer DE, Buzzai M, Karnauskas R, Harris MH, Plas DR et al. Akt stimulates aerobic glycolysis in cancer cells. Cancer Res 2004; 64: 3892-3899.

108. Shackelford DB, Shaw RJ. The LKB1-AMPK pathway: metabolism and growth control in tumour suppression. Nat Rev Cancer 2009; 9: 563-575.

109. Kim JW, Tchernyshyov I, Semenza GL, Dang CV. HIF-1-mediated expression of pyruvate dehydrogenase kinase: a metabolic switch required for cellular adaptation to hypoxia. Cell Metabol 2006; 3: 177-185.

110. Libby G, Donnelly LA, Donnan PT, Alessi DR, Morris AD, Evans JM. New users of metformin are at low risk of incident cancer: a cohort study among people with type 2 diabetes. Diabetes Care 2009; 32: 1620-1625.

111. Braakhuis BJ, Leemans $\mathrm{CR}$, Brakenhoff RH. Expanding fields of genetically altered cells in head and neck squamous carcinogenesis. Semin Cancer Biol 2005; 15: 113-120.

112. Reya T, Morrison SJ, Clarke MF, Weissman IL. Stem cells, cancer, and cancer stem cells. Nature 2001; 414: 105-111.

113. Brunner TB, Kunz-Schughart LA, Grosse-Gehling P, Baumann M. Cancer stem cells as a predictive factor in radiotherapy. Semin Radiat Oncol 2012; 22: 151-174.

114. Zoller M. CD44: can a cancer-initiating cell profit from an abundantly expressed molecule? Nat Rev Cancer 2011; 11: 254-267.

115. Prince ME, Sivanandan R, Kaczorowski A, Wolf GT, Kaplan MJ, Dalerba P et al. Identification of a subpopulation of cells with cancer stem cell properties in head and neck squamous cell carcinoma. Proc Natl Acad Sci USA 2007; 104: 973-978.

116. Bracken AP, Dietrich N, Pasini D, Hansen KH, Helin K. Genome-wide mapping of Polycomb target genes unravels their roles in cell fate transitions. Genes Dev 2006; 20 : 1123-1136.

117. Mack B, Gires O. CD44s and CD44v6 expression in head and neck epithelia. PLoS One 2008; 3: e3360

118. Ma I, Allan AL. The role of human aldehyde dehydrogenase in normal and cancer stem cells. Stem Cell Rev 2011; 7: 292-306.

119. Krishnamurthy S, Dong Z, Vodopyanov D, Imai A, Helman JI, Prince ME et al. Endothelial cell-initiated signaling promotes the survival and self-renewal of cancer stem cells. Cancer Res 2010; 70: 9969-9978.

120. Chen YC, Chen YW, Hsu HS, Tseng LM, Huang PI, Lu KH et al. Aldehyde dehydrogenase 1 is a putative marker for cancer stem cells in head and neck squamous cancer. Biochem Biophys Res Commun 2009; 385: 307-313.

121. Faber A, Barth C, Hormann K, Kassner S, Schultz JD, Sommer U et al. CD44 as a stem cell marker in head and neck squamous cell carcinoma. Oncol Rep 2011; 26: 321-326.

122. Joshua B, Kaplan MJ, Doweck I, Pai R, Weissman IL, Prince ME et al. Frequency of cells expressing CD44, a head and neck cancer stem cell marker: correlation with tumor aggressiveness. Head Neck 2012; 34: 42-49. 
123. de Jong MC, Pramana J, van der Wal JE, Lacko M, Peutz-Kootstra CJ, de Jong JM et al. CD44 expression predicts local recurrence after radiotherapy in larynx cancer. Clin Cancer Res 2010; 16: 5329-5338.

124. Riechelmann H, Sauter A, Golze W, Hanft G, Schroen C, Hoermann K et al. Phase I trial with the CD44v6-targeting immunoconjugate bivatuzumab mertansine in head and neck squamous cell carcinoma. Oral Oncol 2008; 44: 823-829.

125. Braakhuis BJ, Brakenhoff $\mathrm{RH}$, Leemans $\mathrm{CR}$. Gene expression profiling in head and neck squamous cell carcinoma. Curr Opin Otolaryngol Head Neck Surg 2010; 18: 67-71.

126. Roepman P, Wessels LF, Kettelarij N, Kemmeren $P$, Miles AJ, Lijnzaad $P$ et al. An expression profile for diagnosis of lymph node metastases from primary head and neck squamous cell carcinomas. Nat Genet 2005; 37: 182-186.

127. Torres-Roca JF, Eschrich S, Zhao H, Bloom G, Sung J, McCarthy S et al. Prediction of radiation sensitivity using a gene expression classifier. Cancer Res 2005; 65: 7169-7176.

128. Bartel DP, Chen $\mathrm{CZ}$. Micromanagers of gene expression: the potentially widespread influence of metazoan microRNAs. Nat Rev Genet 2004; 5: 396-400.

129. Lu Z, Liu M, Stribinskis V, Klinge CM, Ramos KS, Colburn NH et al. MicroRNA-21 promotes cell transformation by targeting the programmed cell death 4 gene. Oncogene 2008; 27 : 4373-4379.

130. Ivanovska I, Ball AS, Diaz RL, Magnus JF, Kibukawa M, Schelter JM et al. MicroRNAs in the miR-106b family regulate p21/CDKN1A and promote cell cycle progression. Mol Cell Biol 2008; 28: 2167-2174.

131. Childs G, Fazzari M, Kung G, Kawachi N, Brandwein-Gensler M, McLemore M et al. Lowlevel expression of microRNAs let-7d and miR-205 are prognostic markers of head and neck squamous cell carcinoma. Am J Pathol 2009; 174: 736-745.

132. Qu C, Liang Z, Huang J, Zhao R, Su C, Wang S et al. MiR-205 determines the radioresistance of human nasopharyngeal carcinoma by directly targeting PTEN. Cell Cycle 2012; 11: 785-796

133. Avissar M, Christensen BC, Kelsey KT, Marsit CJ. MicroRNA expression ratio is predictive of head and neck squamous cell carcinoma. Clinical cancer research: an official journal of the American Association for Cancer Research 2009; 15: 2850-2855.
134. Chang KW, Liu CJ, Chu TH, Cheng HW, Hung PS, Hu WY et al. Association between high miR-211 microRNA expression and the poor prognosis of oral carcinoma. J Dent Res 2008; 87: 1063-1068.

135. Yang CC, Hung PS, Wang PW, Liu CJ, Chu TH, Cheng HW et al. miR-181 as a putative biomarker for lymph-node metastasis of oral squamous cell carcinoma. J Oral Pathol Med 2011; 40: 397-404.

136. Johnson SM, Grosshans H, Shingara J, Byrom M, Jarvis R, Cheng A et al. RAS is regulated by the let-7 microRNA family. Cell 2005; 120: 635-647.

137. Israelsen WJ, Dayton TL, Davidson SM, Fiske BP, Hosios AM, Bellinger G et al. PKM2 isoform-specific deletion reveals a differential requirement for pyruvate kinase in tumor cells. Cell 2013; 155: 397-409.

138. Kinoshita T, Nohata N, Fuse M, Hanazawa T, Kikkawa N, Fujimura L et al. Tumor suppressive microRNA-133a regulates novel targets: moesin contributes to cancer cel proliferation and invasion in head and neck squamous cell carcinoma. Biochem Biophys Res Commun 2012; 418: 378-383.

139. Korpal M, Lee ES, Hu G, Kang Y. The miR-200 family inhibits epithelialmesenchymal transition and cancer cell migration by direct targeting of E-cadherin transcriptional repressors ZEB1 and ZEB2. J Biol Chem 2008; 283: 14910-14914.

140. Dai $Y$, Xie $\mathrm{CH}$, Neis JP, Fan CY, Vural E, Spring PM. MicroRNA expression profiles of head and neck squamous cell carcinoma with docetaxel-induced multidrug resistance. Head Neck 2011; 33: 786-791.

(1)(2) Cell Death and Disease is an open-access journal published by Nature Publishing Group. This work is licensed under a Creative Commons Attribution-NonCommercialShareAlike 3.0 Unported License. To view a copy of this license, visit http://creativecommons.org/licenses/by-nc-sa/3.0/ 